\title{
PEMBELAJARAN FISIKA MENGGUNAKAN MEDIA ANIMASI MACROMEDIA FLASH-MX DAN GAMBAR UNTUK MENINGKATKAN PEMAHAMAN KONSEP MAHASISWA
}

\author{
Hadma Yuliani \\ Tadris Fisika, Institus Agama Islam Negeri Palangka Raya, Jl. G. Obos, Palangka Raya \\ Email: hadma.yuliani@ iain-palangkaraya.ac.id
}

Diterima: 5 Februari 2017. Disetujui: 8 April 2017. Dipublikasikan: 28 April 2017

\begin{abstract}
Abstrak: Penelitian ini bertujuan: (1) untuk mengetahui peningkatan pemahaman konsep mahasiswa dengan menggunakan Media Animasi Macromedia Flash - MX dan Gambar pada mata kuliah Fisika Kuantum; (2) Untuk mengetahui respon mahasiswa setelah diterapkan Media Animasi Macromedia Flash - MX dan Gambar pada mata kuliah Fisika Kuantum. Hasil penelitian menunjukkan bahwa: (1) Nilai pretest pemahaman sebelum dilaksanakan pembelajaran oleh peneliti sebesar $(33,02)$ tidak jauh berbeda dengan nilai pada post test $(46,25)$, nilai gain yang diperoleh sebesar $(13,23)$, nilai $\mathrm{N}$-gain yang diperoleh $(0,19)$ dengan kategori rendah. Terdapat peningkatan pembelajaran fisika kuantum dengan menggunakan Media Animasi Macromedia Flash - MX dan Gambar pada mata kuliah Fisika Kuantum dengan kategori rendah; (2) Respon mahasiswa terhadap pembelajaran fisika kuantum dengan menggunakan Media Animasi Macromedia Flash - MX dan Gambar pada mata kuliah Fisika Kuantum pada umumnya siswa menyatakan senang (100\%), siswa merasa baru (100\%), dan siswa merasa bermanfaat (100 \%), Respon untuk perasaan mahasiswa terhadap Lembar Kerja Mahasiswa (LKM) aplikasi persamaan Schrodinger untuk sistem potensial sederhana umumnya menyatakan sulit (85\%) dan respon mahasiswa untuk soal-soal aplikasi persamaan Schrodinger untuk sistem potensial sederhana dianggap masih sulit (90\%).
\end{abstract}

Kata Kunci: media animasi, media gambar, macromedia flash- MX, pemahaman konsep, respon siswa.

\section{PHYSICS LEARNING USING MACROMEDIA FLASH-MX ANIMATION MEDIA AND PICTURE TO IMPROVE STUDENTS' CONCEPTS UNDERSTANDING}

\begin{abstract}
The objectives of the study are: (1) to measure the improvement of the conceptual understanding of the students by using Animated Macromedia Flash - MX and Picture in Quantum Physics Subject; (2) to describe the respond of students after using Animated Macromedia Flash - MX and Picture in Quantum Physics Subject. The result of the study shows that: (1) The Pretest score of understanding before using Animated Macromedia Flash - MX and Picture are 33,02, which is not significantly different from post-test score 46,25, The gain score achieved is 13,23, the $N$-gain score achieved is 0,19 with low category. There is an improvement of teaching-learning Quantum Physics subject using Animated Macromedia Flash - MX and Picture with low category; (2) the students' response toward teaching and learning of Quantum Physics subject using Animated Macromedia Flash - MX and Picture are positive (100\%), the students consider the media as something new and beneficial (100\%), the students' response towards Lembar Kerja Mahasiswa (LKM) application of Schrodinger equation for simple potential system is considered difficult (85\%) and the students' response towards the questions of Schrodinger equation for simple potential system are still considered difficult (90\%).
\end{abstract}

(C) 2017 Pendidikan Fisika FTK UIN Raden Intan Lampung

Keywords: animation media, concept understanding, macromedia flash-MX, picture media, student response. 


\section{PENDAHULUAN}

Fisika merupakan ilmu sains yang paling fundamental, dikarenakan mempelajari prinsip-prinsip dasar dari alam semesta. Fisika adalah ilmu yang menjadi dasar bagi ilmu sains lainnya seperti Astronomi, Biologi, Kimia, dan Geologi. Keindahan dari Fisika terletak dari sederhananya teori-teori Fisika yang penting dan terletak pada cara menggunakan sedikit konsep, persamaan, dan asumsi fundamental yang dapat mengubah dan mengembangkan pandangan dunia di sekitar kita. Ilmu Fisika dapat dibagi menjadi enam bidang utama yaitu mekanika klasik, relativitas, termodinamika, elektromagnetisme, optika, dan mekanika kuantum (Serway dan Jewett, 2010)

Mekanika kuantum berkembang dari penyelesaian Max Planck tahun 1900 pada masalah radiasi benda-hitam (dilaporkan 1859) dan paper Albert Einstein tahun 1905 yang menawarkan teori berbasiskuantum untuk menjelaskan efek fotolistrik (dilaporkan 1887) (Suparmi, 2011). Teori kuantum lama dipahami secara mendalam pada pertengahan 1920an. Teori Fisika Kuantum berkembang sampai saat ini dan diajarkan kepada mahasiswa pendidikan fisika maupun fisika yang dijadikan sebagai salah satu mata kuliah di perguruan tinggi.

Fisika Kuantum merupakan salah satu mata kuliah wajib program studi di Tadris Fisika IAIN Palangka Raya yang diprogramkan di semester VI. Fisika Kuantum merupakan mata kuliah yang mempelajari mengenai perilaku dari materi dan energi pada molekul, atom, nuklir, dan tingkat mikroskopik hingga lebih kecil. Fisika Kuantum memulai observasi pada benda yang sangat kecil bahkan lebih kecil lagi dari atom. Benda tersebut tidak bisa dilihat oleh mata telanjang untuk diamati secara langsung.

Fisika Kuantum merupakan mata kuliah yang sangat penting untuk diajarkan terhadap mahasiswa dikarenakan teori Fisika Kuantum ini muncul pada akhir abad kesembilan belas. Fisika Kuantum muncul dikarenakan hasil eksperimen tidak bisa dijelaskan menggunakan teori yang digunakan pada saat itu (fisika klasik) (Suparmi, 2011). Fisika Kuantum merupakan basis utama untuk memahami alam semesta. Namun, terkadang kebanyakan perkuliahan atau pembelajaran konsep ini berupaya untuk mengabaikannya dikarenakan mahasiswa selama ini menganggap Fisika Kuantum adalah topik yang mikroskopik, mempelajari hal-hal yang tidak teramati langsung oleh indera, dan membutuhkan pemahaman tingkah tinggi (Hobson, 1996)

Berdasarkan observasi yang dilakukan pada kelas Fisika Kuantum, masih terdapat rendahnya penguasaan matematis mahasiswa, banyaknya materi Fisika Kuantum yang bersifat abstrak, kegiatan pembelajaran yang cenderung ceramah, pembelajaran yang kurangnya menggunakan media pembelajaran, kurang kemampuan mandiri siswa dalam menyelesaikan soal-soal, dan kemampuan penilaian yang hanya berorientasi pada tugas, UTS, dan UAS.

Hasil wawancara dengan mahasiswa diperoleh bahwa materi Fisika Kuantum susah dipahami karena perlu penguasaan matematis yang tinggi, peristiwa yang terjadi dalam Fisika Kuantum tidak mampu diamati secara langsung dengan indera mata. Upaya mengamati peristiwa yang terjadi dalam mempelajari materi Fisika Kuantum yang bersifat abstrak, diperlukan berbagai pendekatan pembelajaran (Saregar, 2016). 
Pendidik diharapkan dapat memilih berbagai pendekatan pembelajaran yang sesuai seperti pendekatan keterampilan proses (Yuliani et al., 2012), menggunakan berbagai variasi model pembelajaran seperti model Kooperatif (Kumala Sari et al, 2015) dan model Learning Cycle (Astupura \& Yuliani, 2015; Astupura \& Yuliani, 2016) dan media pembelajaran yang sesuai dengan materi pembelajaran sehingga pembelajaran dapat berjalan secara efektif dan efisien. Penggunaan media pembelajaran akan membantu mahasiswa dalam memahami materi perkuliahan seperti Fisika Kuantum yang bersifat abstrak. Namun, penggunaan media disesuaikan dengan karakteristik materi yang diajarkan dan karakteristik mahasiswa.

Media pembelajaran sangat beragam dalam perkuliahan fisika seperti KIT yang didemonstrasikan, media software simulasi seperti Macromedia Flash MX, media gambar dan lain-lainnya. Media Macromedia Flash MX adalah soft ware canggih yang diharapkan dapat membantu mahasiswa dalam memahami materi pembelajaran Fisika Kuantum yang bersifat abstrak yang diharapkan agar mampu memudahkan mahasiswa memahami konsep pada Fisika Kuantum. Hal ini sesuai dengan, Kelebihan Macromedia Flash MX yang telah dilakukan yaitu penggunaan media pembelajaran IM3 berbasis flash dan media MS. Power Point terhadap prestasi belajar IPA-Fisika di SMPN 1 Madiun. Hasil penelitian menunjukkan bahwa siswa di SMPN 1 Madiun yang diajar menggunakan media IM3 berbasis flash memberikan rata-rata prestasi lebih baik dibandingkan dengan siswa yang diajar menggunakan power point. Siswa di SMPN 1 Madiun dengan motivasi belajar tinggi menghasilkan rata-rata prestasi lebih baik daripada siswa dengan motivasi belajar rendah, serta terdapat interaksi motivasi belajar dengan media pembelajaran terhadap prestasi belajar IPA-Fisika. Siswa dengan motivasi belajar tinggi menghasilkan rata-rata prestasi lebih baik daripada siswa dengan motivasi belajar rendah, serta terdapat interaksi motivasi belajar dengan media pembelajaran terhadap prestasi belajar IPA-Fisika (Handika, 2012).

Penelitian ini diharapkan mampu meningkatkan pemahaman konsep mahasiswa. Oleh karena itu, media pembelajaran yang sesuai dengan karakteristik materi pembelajaran.

Berbagai penelitian menyatakan bahwa pembelajaran Fisika Kuantum dengan menggunakan media pembelajaran berbasis multi representasi dapat meningkatkan pemahaman konsep Fisika Kuantum mahasiswa di Universitas Lampung pada materi efek fotolistrik, model atom Bohr dan persamaan Schrodinger (Abdurrahman et al, 2011). Selain itu, penggunaan media animasi berbasis Visual Basic (VBA) Spreedsheet Excel dapat meningkatkan pemahaman konsep mahasiswa dan menumbuhkan motivasi belajar mahasiswa pada materi potensial osilator harmonic sederhana (Nurhayati, 2015). Berdasarkan penelitian yang ada, peneliti tertarik untuk menggunakan penerapan media animasi Macromedia Flash-MX dan gambar diharapkan untuk mempermudah pemahaman konsep mahasiswa.

Tujuan penelitian yang ingin dicapai pada penelitian ini adalah (1) untuk mengetahui peningkatan pemahaman konsep mahasiswa dengan menggunakan Media Animasi Macromedia Flash - MX dan Gambar pada mata kuliah Fisika Kuantum; (2) Untuk mengetahui respon mahasiswa setelah diterapkan Media 
Animasi Macromedia Flash - MX dan Gambar pada mata kuliah Fisika Kuantum.

Penelitian ini diharapkan sebagai bahan refleksi dan evaluasi bagi pendidik fisika agar dapat mengetahui pengaruh pemahaman konsep mahasiswa setelah diterapkan Media Animasi Macromedia Flash - MX dan Gambar pada mata kuliah Fisika Kuantum dan dapat memberikan alternative gambaran kepada dosen dalam menentukan penggunaan media pembelajaran pada mata kuliah Fisika Kuantum

Penelitian ini dibatasi pada variabel pemahaman konsep fisika mahasiswa. Adapun materi Fisika Kuantum yang dimaksud dalam penelitian ini dibatasi pada Aplikasi persamaan Schrodinger untuk sistem potensial kotak satu dimensi dan dua dimensi.

\section{METODE PENELITIAN}

Penelitian ini menggunakan pendekatan Kuantitatif. Jenis penelitian yang dilakukan yaitu penelitian deskriptif (Arikunto, 2003). Penelitian ini dilaksanakan di Laboratorium Fisika Program Studi Tadris Fisika Jurusan PMIPA FTIK IAIN Palangka Raya tahun Ajaran 2015/2016. Pelaksanaan penelitian dilaksanakan bulan Mei-Juli 2016.

Penelitian terdiri atas empat tahapan, yaitu tahap persiapan (observasi, menentukan sampel, dan membuat istrumen, validasi instrumen); tahap pelaksanaan penelitian (pretest, sampel diberikan pembelajaran menggunakan Media Animasi Macromedia Flash - MX dan Gambar, posttest, penyebaran angket respon mahasiswa); tahap analisis data (menganalisis pretest dan posttest serta angket respon mahasiswa); dan tahap menyimpulkan.

Peneliti mengambil mahasiswa semester VI yang memprogram mata kuliah Fisika Kuantum tahun ajaran 2015/2016 di Tadris Fisika Fisika Jurusan PMIPA FTIK IAIN Palangka Raya sebagai populasi penelitian. Pengambilan sampel menggunakan teknik purposive sampling yaitu teknik pengambilan sampel dengan pertimbangan tertentu berdasarkan kemampuan mahasiswa dari hasil pengamatan peneliti.

Teknik pengumpulan data yang digunakan dalam penelitian ini antara lain: metode tes untuk mengetahui pemahaman konsep.; dan metode angket untuk mengetahui respon mahasiswa yang dianalisis data respon mahasiswa untuk mengetahui pendapat mahasiswa terhadap KBM.

Instrumen pengambilan data digunakan tes. Peningkatan hasil pemahaman konsep mahasiswa dianalisis menggunakan n-gain untuk mengetahui peningkatan kemampuan pemahaman konsep. Angket digunakan untuk mengetahui respon mahasiswa mengenai kegiatan belajar mengajar.

\section{HASIL DAN PEMBAHASAN}

Rekapitulasi nilai pemahaman konsep mahasiswa (pre-test) sebelum diterapkan media animasi Macromedia Flash - MX dan gambar, serta nilai posttest setelah penerapan media animasi Macromedia Flash - MX dan gambar dalam pembelajaran, dapat dilihat seperti pada tabel 1 berikut: 
Tabel 1. Rekapitulasi Nilai Pre-test, post-test, Gain, N-Gain

\begin{tabular}{ccccrr}
\hline No & Nama Siswa & Pretes & Postes & \multicolumn{1}{c}{ Gain } & N gain \\
\hline 1 & A1 & 43.32 & 55 & 11.68 & 0.21 \\
2 & B1 & 13.65 & 23.32 & 9.67 & 0.11 \\
3 & C1 & 43.32 & 36.65 & -6.67 & -0.12 \\
4 & D1 & 36.65 & 36.65 & 0 & 0.00 \\
5 & E1 & 26.65 & 53 & 26.35 & 0.36 \\
\hline 6 & F1 & 33 & 43.32 & 10.32 & 0.15 \\
7 & G1 & 56.65 & 60 & 3.35 & 0.08 \\
8 & H1 & 13 & 33 & 20 & 0.23 \\
9 & I1 & 23 & 50 & 27 & 0.35 \\
10 & J1 & 23 & 43.32 & 20.32 & 0.26 \\
11 & K1 & 36 & 60 & 24 & 0.38 \\
12 & L1 & 53 & 50 & -3 & -0.06 \\
13 & M1 & 25 & 33 & 8 & 0.11 \\
14 & N1 & 33 & 40 & 7 & 0.10 \\
15 & O1 & 56 & 70 & 14 & 0.32 \\
16 & P1 & 43.65 & 43.32 & -0.33 & -0.01 \\
17 & Q1 & 20 & 33 & 13 & 0.16 \\
18 & R1 & 36.65 & 65 & 28.35 & 0.45 \\
19 & S1 & 20 & 53 & 33 & 0.41 \\
20 & T1 & 25 & 43.65 & 18.65 & 0.25 \\
\hline
\end{tabular}

Hasil rata-rata pemahaman konsep mahasiswa dengan menerapkan Media Animasi Macromedia Flash -
MX dan Gambar dapat dilihat pada tabel 2 berikut:

\section{Tabel 2. Rata-rata Pemahaman Konsep Mahasiswa}

\begin{tabular}{cccc}
\hline Pretest & Postest & Gain & N gain \\
\hline 33,02 & 46,25 & 13,23 & 0,19 \\
\hline
\end{tabular}

Data Tabel 1 dan 2 di atas terlihat nilai pretest pemahaman sebelum dilaksanakan pembelajaran oleh peneliti sebesar $(33,02)$ tidak jauh berbeda dengan nilai pada post test $(46,25)$, nilai gain yang diperoleh sebesar $(13,23)$, nilai $\mathrm{N}$-gain yang diperoleh $(0,19)$ dengan kategori rendah. Tabel 1 dan 2 di atas terlihat nilai pretest pemahaman sebelum dilaksanakan pembelajaran oleh peneliti sebesar $(33,02)$ tidak jauh berbeda dengan nilai pada post test $(46,25)$, nilai gain yang diperoleh sebesar $(13,23)$, nilai $\mathrm{N}$-gain yang diperoleh $(0,19)$ dengan kategori rendah. Hal ini dikarenakan Kemampuan menyatakan ulang sebuah konsep, Mengklasifikan objek-objek menurut sifatsifat tertentu (sesuai dengan konsepnya), Memberikan contoh dan non contoh dari konsep, Menyajikan konsep dalam berbagai bentuk representasi matematis, Mengembangkan syarat perlu atau syarat 
cukup suatu konsep, Mengklasifikasikan konsep atau algoritma pemecahan masalah yaitu mampu menyajikan konsep dalam berbagai bentuk representasi matematis sebagai suatu logaritma pemecahan masalah dimiliki mahasiswa masih rendah. Selain itu juga, dikarenakan kemampuan menguasai konsep matematis mahasiswa rendah, dan materi fisika Kuantum khususnya potensial sederhana sulit dipahami mahasiswa karena konteks di kehidupan sehari-hari jarang ditemukan mahasiswa. Namun ada peningkatan mahasiswa dilihat dari N-gain sebesar 0,19 dengan kategori rendah yang menunjukkan masih ada peningkatan pemahaman konsep mahasiswa dengan menggunakan Media animasi Macromedia Flash-MX.

Hal ini sejalan, Penelitian yang dilakukan oleh Su \& Yeh (2015), yaitu semua hasil statistik menunjukkan bahwa Instruksi animasi fisika adalah untuk memperkaya teks fisika, untuk memajukan prestasi belajar positif siswa jurusan teknik yang mengikuti kursus fisika. Hasil penelitian ini juga memberikan kontribusi besar terhadap hasil belajar kinerja siswa yang meningkatkan pemahaman fisika siswa. Selain itu, Penelitian yang dilakukan oleh Handika (2012) yang menunjukkan bahwa siswa yang diajar menggunakan media IM3 berbasis flash memberikan ratarata prestasi lebih baik dibandingkan dengan siswa yang diajar mengguna- kan power point. Siswa dengan motivasi belajar tinggi menghasilkan rata-rata prestasi lebih baik daripada siswa dengan motivasi belajar rendah.

Respon mahasiswa dimaksudkan untuk melihat pendapat dan perasaan mahasiswa setelah diterapkan media animasi Macromedia Flash - MX dan gambar pada mata kuliah Fisika Kuantum yang telah dilaksanakan di kelas. Respon mahasiswa terhadap pembelajaran setelah diterapkan media animasi Macromedia Flash - MX dan gambar pada mata kuliah Fisika Kuantum meliputi perasaan selama mengikuti kegiatan belajar mengajar (KBM), kesan terhadap cara penyajian materi oleh dosen, lembar kerja Mahasiswa (LKM), materi pelajaran, suasana belajar di kelas, kesan apakah media animasi Macromedia Flash - MX dan gambar pada mata kuliah Fisika Kuantum baru bagi mahasiswa, kesan apakah diterapkan media animasi Macromedia Flash - MX dan gambar pada mata kuliah Fisika Kuantum memudahkan mahasiswa dalam memahami materi pelajaran, kesan apakah cara penyajian baru bagi mahasiswa, lembar kerja siswa (LKPD), suasana belajar, kesan apakah materi menarik bagi mahasiswa, kesan apakah lembar kerja Mahasiswa (LKM) bagi mahasiswa menarik, soal-soal di lembar kerja Mahasiswa (LKM). Respon mahasiswa terhadap kegiatan belajar mengajar (KBM) dapat dilihat pada tabel 3. 
Tabel 3. Respon Mahasiswa

\begin{tabular}{|c|c|c|c|c|c|}
\hline \multirow[t]{2}{*}{ No } & \multirow[t]{2}{*}{ Pertanyaan } & \multicolumn{2}{|c|}{ Senang } & \multicolumn{2}{|c|}{ Tidak Senang } \\
\hline & & $\mathbf{F}$ & $\%$ & $\mathbf{F}$ & $\%$ \\
\hline 1. & $\begin{array}{l}\text { Bagaimana pendapat Anda selama mengikuti } \\
\text { kegiatan pembelajaran dengan diterapkan Media } \\
\text { Animasi Macromedia Flash - MX dan Gambar? }\end{array}$ & 15 & 100 & 0 & 0 \\
\hline \multirow[t]{8}{*}{2.} & Bagaimana perasaan Anda terhadap: & & & & \\
\hline & a. Materi pelajaran aplikasi & 15 & 75 & 5 & 25 \\
\hline & $\begin{array}{l}\text { Schrodınger untuk sistem potensial } \\
\text { sederhana? }\end{array}$ & 17 & 85 & 3 & 15 \\
\hline & b. Lembar Kerja Mahasiswa (LKM) persamaan & & & & \\
\hline & $\begin{array}{l}\text { Schrodinger untuk sistem potensial } \\
\text { sederhana? }\end{array}$ & 16 & 80 & 4 & 20 \\
\hline & c. Suasana belajar di kelas? & & & & \\
\hline & & \multicolumn{2}{|c|}{ Baru } & \multicolumn{2}{|c|}{ Tidak Baru } \\
\hline & & $\mathbf{F}$ & $\%$ & $\mathbf{F}$ & $\%$ \\
\hline 3. & $\begin{array}{l}\text { Bagaimana pendapat Anda tentang kegiatan } \\
\text { pembelajaran fisika Kuantum dengan diterapkan } \\
\text { Media Animasi Macromedia Flash - MX dan } \\
\text { Gambar? }\end{array}$ & 20 & 100 & 0 & 0 \\
\hline \multirow[t]{6}{*}{4.} & Bagaimana pendapat Anda terhadap: & & & & \\
\hline & a. Materi pelajaran aplikasi persamaan & 20 & 100 & 0 & 0 \\
\hline & $\begin{array}{l}\begin{array}{l}\text { Schrodinger untuk sistem } \\
\text { sederhana? }\end{array} \text { potensial }\end{array}$ & 20 & 100 & 0 & 0 \\
\hline & $\begin{array}{l}\text { b. Lembar Keja Peserta Didik (LKPD) aplikasi } \\
\text { persamaan Schrodinger untuk sistem } \\
\text { potensial sederhana? }\end{array}$ & 20 & 100 & 0 & 0 \\
\hline & c. Soal-soal tentang aplikasi persamaan & & & & \\
\hline & $\begin{array}{l}\text { Schrodinger untuk sistem potensial } \\
\text { sederhana? }\end{array}$ & 15 & 75 & 5 & 25 \\
\hline
\end{tabular}

5. Bagaimana perasaan Anda terhadap:

a. Lembar Kerja Mahasiswa (LKM) aplikasi

\begin{tabular}{cccc} 
Mudah & \multicolumn{3}{c}{ Sulit } \\
\hline F & $\%$ & F & \% \\
3 & 15 & 17 & 85
\end{tabular}
persamaan Schrodinger untuk sistem potensial sederhana?

b. Soal-soal aplikasi persamaan Schrodinger untuk sistem potensial sederhana?

$\begin{array}{llll}2 & 10 & 18 & 90\end{array}$

\begin{tabular}{|c|c|c|c|c|c|}
\hline & & \multicolumn{2}{|c|}{ Bermanfaat } & \multicolumn{2}{|c|}{$\begin{array}{c}\text { Tidak } \\
\text { Bermanfaat }\end{array}$} \\
\hline & & $\mathbf{F}$ & $\%$ & $\mathbf{F}$ & $\%$ \\
\hline \multirow[t]{3}{*}{6.} & $\begin{array}{l}\text { Apakah pembelajaran Fisika Kuantum diterapkan } \\
\text { Media Animasi Macromedia Flash - MX dan } \\
\text { Gambar ini bermanfaat bagi Anda? }\end{array}$ & 20 & 100 & 0 & 0 \\
\hline & & \multicolumn{2}{|c|}{ Ya } & \multicolumn{2}{|c|}{ Tidak } \\
\hline & & $\mathbf{F}$ & $\%$ & $\mathbf{F}$ & $\%$ \\
\hline 7. & $\begin{array}{l}\text { Apakah pembelajaran Fisika Kuantum dengan } \\
\text { diterapkan Media Animasi Macromedia Flash - } \\
\text { MX dan Gambar membuat anda lebih mudah } \\
\text { memahami materi pembelajaran? }\end{array}$ & 15 & 75 & 5 & 25 \\
\hline
\end{tabular}


Respon mahasiswa terhadap pembelajaran fisika kuantum menggunakan media animasi Macromedia Flash - MX dan gambar pada mata kuliah Fisika Kuantum, umumnya mahasiswa menyatakan senang (100\%), mahasiswa merasa baru (100 \%), dan mahasiswa merasa bermanfaat $(100 \%)$. Tetapi, Respon untuk perasaan mahasiswa terhadap Lembar Kerja Mahasiswa (LKM), aplikasi persamaan Schrodinger untuk sistem potensial sederhana umumnya menyatakan sulit (85\%) dan respon mahasiswa untuk soal-soal aplikasi persamaan Schrodinger untuk sistem potensial sederhana dianggap masih sulit (90\%). Hal ini, dikarenakan perlunya penguasaan matematika yang membantu mahasiswa menguasai konsep materi tersebut, dan keterbatasan media animasi yang masih kurang mampu menjelaskan materi pembelajaran secara spesifik.

Hal ini sejalan dengan penelitian yang dilakukan Sarabando et al (2014) yang menunjukkan Hasil total gain lebih tinggi saat siswa menggunakan simulasi komputer, sendiri atau bersama-sama dengan "hands-on". Hal ini menunjukkan bahwa ada kontribusi simulasi komputer terhadap pembelajaran konsep fisika siswa (Berat dan massa) terhadap pemahaman siswa kelas 7. Namun, total gain yang didapat bergantung pada pedagogik para guru saat menggunakan simulasi komputer untuk mengajarkan terhadap siswa. Jadi, sejalan dengan penelitian terdahulu dan penelitian yang dilakukan dapat disimpulkan perlunya penguasaan matematika yang membantu mahasiswa menguasai konsep materi tersebut, dan keterbatasan media animasi yang masih kurang mampu menjelaskan materi pembelajaran secara spesifik sehingga perlu keterampilan pedagogik yang dimiliki dosen.

\section{SIMPULAN DAN SARAN \\ Simpulan}

Berdasarkan hasil analisis data dan pembahasan dapat diambil suatu kesimpulan sebagai berikut:

1. Terdapat peningkatan pemahaman konsep dalam pembelajaran fisika kuantum dengan menggunakan media animasi Macromedia Flash - MX dan gambar pada mata kuliah Fisika Kuantum dengan kategori rendah.

2. Respon mahasiswa terhadap pembelajaran fisika kuantum dengan menggunakan media animasi Macromedia Flash - MX dan gambar pada mata kuliah Fisika Kuantum pada umumnya siswa menyatakan senang (100\%), siswa merasa baru (100\%), dan siswa merasa bermanfaat $(100 \%)$, Respon untuk perasaan mahasiswa terhadap Lembar Kerja Mahasiswa (LKM), aplikasi persamaan Schrodinger untuk sistem potensial sederhana umumnya menyatakan sulit $(85 \%)$ dan respon mahasiswa untuk soal-soal aplikasi persamaan Schrodinger sistem potensial sederhana dianggap masih sulit $(90 \%)$.

\section{Saran}

Berdasarkan kesimpulan penelitian, dapat disarankan beberapa hal yaitu pembelajaran dengan media animasi Macromedia Flash - MX dan gambar pada mata kuliah Fisika Kuantum ini dapat dijadikan pilihan alternatif media pembelajaran bagi tenaga pengajar dan dapat diteliti lebih lanjut menggunakan media yang berbeda.

\section{UCAPAN TERIMA KASIH}

Peneliti mengucapkan terima kasih kepada IAIN Palangka Raya yang telah memberikan bantuan hibah penelitian individu berdasarkan Surat Keputusan 
Rektor IAIN Palangka Raya Nomor 216 Tahun 2016, Bapak Suhartono, M. Si., yang telah memberikan masukan mengenai penelitian ini dan semua pihak yang telah memberikan masukan dan bantuan dalam penelitian.

\section{DAFTAR PUSTAKA}

Arikunto, S. (2003). Manajemen Penelitian, Jakarta: PT. Rineka Cipta.

Abdurrahman et al. (2011). Implementasi Pembelajaran Berbasis Multi Representasi Untuk Meningkatkan Penguasaan Konsep Fisika Kuantum. Seminar Cakrawala Pendidikan Th.XXX No.1.hal 30.

Astupura, D.A., \& Yuliani, H. (2015). Korelasi Model Pembelajaran Learning Cycle Terhadap Motivasi dan Keterampilan Proses Sains pada Materi Pokok Cahaya. Jurnal EduSains, 3 (2) 112-124.

Astupura, D.A., \& Yuliani, H. (2016). Penerapan Model Pembelajaran Learning Cycle Terhadap Motivasi dan Keterampilan Proses Sains pada Materi Pokok Cahaya. Jurnal EduSains, 4 (2) 15-27.

Handika, J. (2012). Efektivitas Media Pembelajaran Im3 Ditinjau Dari Motivasi Belajar. Jurnal Pendidikan IPA Indonesia, 1 (2) 109-114

Hobson, A. (1996). Teaching Quantum Theory in the Introductory Course. The Physics Teacher, hal. 202-210.

Kumalasari, R., Suptiatin, A., \& Yuliani, H. (2015). Perbandingan Model Pembelajaran Kooperatif Tipe Number Head Together (NHT) dan Student Team Achievement Division
(STAD) Ditinjau dari Sikap Ilmiah Siswa. Jurnal EduSains, 3 (2) 99-111. Nurhayati. (2015). Pengaruh Modul Berbasis Konstruktivis Terhadap Kemandirian Belajar Mahasiswa Pada Mata Kuliah Fisika Kuantum, Jurnal Edukasi dan Matematika, 3 (1) 54-61.

Sarabando, C., Cravino J. P., \& Soares, A. A. (2014). Contribution of a computer simulation to students' learning of the physics concepts of weight and mass. Procedia Technology, 13, pp. $112-121$.

Sardiman, A.M. (2011). Interaksi dan Motivasi Belajar Mengajar. Jakarta: Rajawali Press.

Saregar, A. (2016). Pembelajaran Pengantar Fisika Kuantum dengan Memanfaatkan Media PhET Simulation dan LKM Melalui Pendekatan Saintifik: Dampak Pada Minat dan Penguasaan Konsep Mahasiswa. Jurnal Ilmiah Pendidikan Fisika Al-Biruni, 5(1) 5360.

Serway, R. A. \& Jewett, J. W. (2010). Fisika Untuk Sains dan Teknik Buku 3 Edisi 6. Jakarta: Salemba Teknika.

Su, K-Dow \& Yeh, S-Chuan. (2015). Effective Assessments of Integrated Animations to Explore College Students' Physics Learning Performances. Procedia - Social and Behavioral Sciences. 176, pp. 588595.

Yuliani, H., Sunarno, W., \& Suparmi. (2012). Pembelajaran Fisika dengan Pendekatan Keterampilan Proses dengan Metode Eksperimen dan Demonstrasi Ditinjau dari Sikap Ilmiah dan Kemampuan Analisis. INKUIRI, $\quad 1 \quad$ (3) 207-216 